\title{
THE LINK BETWEEN ACTIVE PULMONARY TUBERCULOSIS AND HIGH BLOOD GLUCOSE LEVEL
}

\author{
Vildana Hadžić, Emir Abdulović, Ermin Hasanović, Emir Halilović, Leila Pašalić, Ermin \\ Agović, Edin Kurtović
}

Summary:Introduction: The possibility of association between diabetes mellitus (DM) and TB represents an important and growing challenge to the global control of TB. Patients with these two conditions may present high rates of treatment failure of TB and increased risk of death.

Aim of the study: The aim of this study is to determine the number of patients with active pulmonary tuberculosis in Central Bosnia, from February 2016 - and until April 2017. according to age and sex. Then, consolidate if there is a correlation between pulmonary tuberculosis with the level of glucose in the blood.

Material and methods: In the period from February 2016 to April 2017. it we found 26 patients with active pulmonary tuberculosis, of which 19 patients are male and seven female. The patients were analyzed in the blood count, among other things, determined by the level of blood glucose (mmol / l) using AMS (Analayze Medical System) according to the manufacturer.

Results: From a total of 26 patients with active pulmonary tuberculosis in four male patients was found sugar level at or above the reference value. From seven female patients with active tuberculosis in four is found that they have high blood glucose levels.

Conclusion: In our study we found that there is a link between patients with high glucose blood level and active pulomonary tuverculosis. We can say that diabetes is associated with a decrease in cellular immunity.

\section{Introduction}

The first report of the association between DM and TB was documented by Avicenna (980-1027 AD) over one thousand years ago. Since that time, the relationship between diabetes mellitus (DM) and tuberculosis (TB), and the nature of their interaction with regards to comorbidity are largely suggested by numerous epidemiological studies (1). Because of the e ect of diabetes on the immune system, risk for active TB disease is higher and treatment outcomes are poorer among persons with diabetes (2). In 2011, the World Health Organization and the International Union Against Tuberculosis and Lung Disease developed a framework for a coordinated response to both diseases and advised screening all TB patients for diabetes (3). Te possibility of association between diabetes mellitus (DM) and TB represents an important and growing challenge to the global control of TB $(4,5)$. Patients with these two conditions may present high rates of treatment failure of $\mathrm{TB}$ and increased risk of death $(6,7)$.
Cases of TB with DM have higher probability of treatment failure of TB and may develop resistance to the drugs used in the treatment. On the other hand, TB can induce glucose intolerance and hinder the glycemic control in individuals with DM (8). Te global prevalence of DM was estimated at $8.3 \%$ (382 million of adults) in 2013, with projection of an increase to $8.8 \%$ (592 million of adults) in 2035 . It is estimated, in 2015, about 5 million deaths in the world due to this disease that a ects all age groups, with a predominance of the group between 45 and 64 years (9). The exact mechanism of their interlinkage is not clearly understood, but some studies suggested that reduced alveolar macrophage activity in TB patients is the main reason making them prone to DM (10). On the other hand, diabetic patients have weak cellular immunity, kidney problems and alveolar angiopathy that ultimately make the conditions favorable for TB infection (11, 12). Poverty and unhygienic life styles are the serious issues for spreading these two diseases. 


\section{Etiology and Pathogenesis}

The following two mechanisms have been proposed to explain the classic complications of diabetes [13]. 1) Polyol pathway. According to this theory, glucose is converted into sorbitol by the action of aldose reductase, which is implicated as the toxin at the root of almost all complications. 2) Production of advanced glycosylation end-products (AGE). This second theory proposes that glucose binds to proteins, lipids, and nucleic acids, giving rise to AGEs that alter their functions. Thus, the binding of glucose to hemoglobin, collagen, or albumin leads to complications dependent on the organ in which the AGEs are deposited (e.g., kidney, nervous system, vascular system or retina, among others).

Macrophage function is also inhibited in individuals with diabetes, with an impairment of the production of reactive oxygen species, and phagocytic and chemotactic function. Hyperglycemia has a direct depressive effect on the respiratory burst. A combination of these dysfunctional processes contributes to an increased risk of TB in diabetes (14). It is worthwhile to mention that both these diseases may simulate the symptoms of the other. Such symptoms that are common to both include lethargy, fatigue, weight loss, fever and loss of appetite. It is not unheard of for people with diabetes to present to the doctor with complaints of worsening of blood glucose control only to find out later that they have TB.

\section{Effects of anti tubercular drugs on the glucose metabolism}

Rifampicin is a potent hepatic enzyme-inducer. It accelerates the metabolism of several oral hypoglycemic agents, especially sulphonylureas and biguanides, and lowers their plasma levels. Therefore it may cause hyperglycemia in diabetic patients using these drugs. In non-diabetics, it augments the intestinal absorption of glucose and may simulate the symptoms of diabetes (15). Isoniazid, in contrast to rifampicin, inhibits the metabolism of oral hypoglycaemic agents and may lead to an increase in the plasma levels of these drugs. Its main interaction is with sulphonylureas, the action of which it antagonizes and worsens the glycemic control of diabetics on this medication. It also impairs the release and action of insulin leading to hyperglycemia even in non-diabetics. Therefore the dosage of insulin should be adjusted while adding and removing these drugs from the patients' prescriptions. Dipetidyl protease inhibitors (the gliptins), a comparatively newer class of hypoglycemic agents, have a theoretical possibility of reducing immunocompetence because of their mechanism of action [16,17]. This effect could possibly worsen the outcome of patients with TB. The risk of developing active tuberculosis is a twostep process, beginning with initial exposure to and infection by Mycobacterium tuberculosis followed by subsequent progression to disease. Studies of diabetes mellitus and tuberculosis generally focus on active tuberculosis disease. This study aimed to determine the frequency of DM among TB patients in midlle Bosnia.

\section{Aim of this study}

The aim of this study is to determine the number of patients with active pulmonary tuberculosis in Central Bosnia, from February 2016 - and until April 2017. according to age and sex. Then, consolidate if there is a correlation between pulmonary tuberculosis with the level of glucose in the blood.

\section{Materials and Methods}

In the period from February 2016 to April 2017. it we found 26 patients with active pulmonary tuberculosis, of which 19 patients are male and seven female. The patients were analyzed in the blood count, among other things, determined by the level of blood glucose (mmol / l) using AMS (Analayze Medical System) according to the manufacturer. Age of the patients participating in the present study ranged between 17-67 years while the median age was 49 years.

The AMS Diagnostics glucose hexokinase method is based on a modification of Slein, using hexokinase and glucose-6-phosphate-dehydrogenase to catalyze the reaction. Glucose is phosphorylated with adenosine triphosphate (ATP) in the reaction catalyzed by hexokinase (HK). The product, glucose-6-phosphate (G6P) is then oxidized with the concomitant reduction of nicotinamide adenine dinucleotide (NAD) to NADH in the reaction catalyzed by glucose-6-phosphate-dehygrogenase (G6PDH). The formation of NADH causes and 
increase in absorbance at $340 \mathrm{~nm}$. The increase is directly proportional to the amount of glucose in the sample.

\section{The procedure of preparing a composition according to Ziel Neelsen}

Samples of sputum were taken in a special separate counter. During the course of preparation and processing in the safety cabinet we prepared under sterile conditions all samples. Dyeing is based on the fact that certain micro-organisms retain the primary color even when exposed to the action of strong discoloration agents, such as mixtures of alcohols and acids. Hence this acid-fast staining or referred to as Acid-fast. The oldest method by ZiehlNeelsen requires heating during the dyeing with carbolfuchsin. Before the dyeing process of the preparation it is necessary to prepare all the equipment and materials used during operation. It is necessary to mark the slide with numbered sample, and leave them on the rack slides. With a sterile disposable loop in the safety chamber a certain amount of sample is transferred to the glass slide, and a circular motion called homogeneous thin smear of the surface of about $2 \mathrm{~cm}$. Preparations that we have made should be left to dry in air for 15 minutes. After a timeout drying, the preparations were fixed by passing through the burner flame, with a smear facing up. Slides need to leave to cool, then cover them. Preparations which were covered with paint must be warmed by passing a flame under preparation until it reaches the evaporation colors. Then washed with running water through the colored compositions, and execute countdown with an concetration $3 \%$ acid alcohol - concentrated hydrochloric acid, $3 \mathrm{ml}-95 \%$, and alcohol $97 \mathrm{ml}$ add concentrated $\mathrm{HCl}$ in $95 \%$ alcohol). Preparations need to be re-wash with water and lay them up. At last we used methylene blue and cover all the slides for about one minute and washed with water and left to dry in air. Under immersion objective we we observed all slides.

\section{Results}

From a total of 26 patients with active pulmonary tuberculosis in four male patients was found sugar level at or above the reference value (Figure 1).

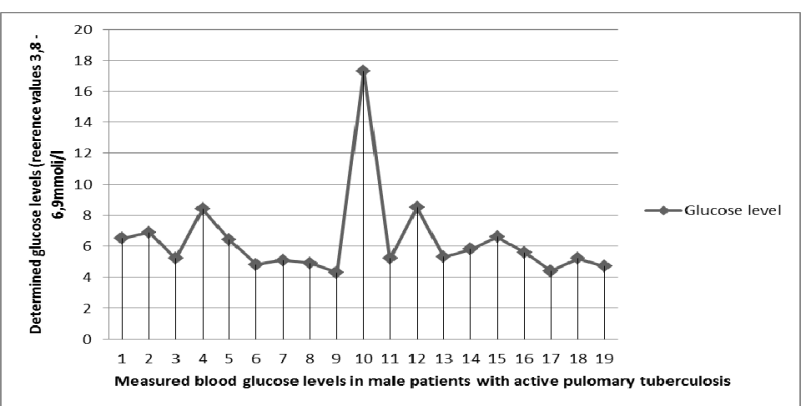

Figure 1. Established blood glucose values in patients with active pulmonary tuberculosis with AMS.

However, from seven female patients with active tuberculosis in four is found that they have high blood glucose levels (Figure 2). In addition, an analysis of the age structure of patients and correlation between TB and diabetes, we see that with age there is a correlation between elevated blood glucose levels and the appearance of active tuberculosis. This fact can be explained this way, with age comes and certainly to a weakening of the immune system, and if we already diagnosed diabetes there is a strong possibility that the person gets tuberculosis if it is exposed to the causer.

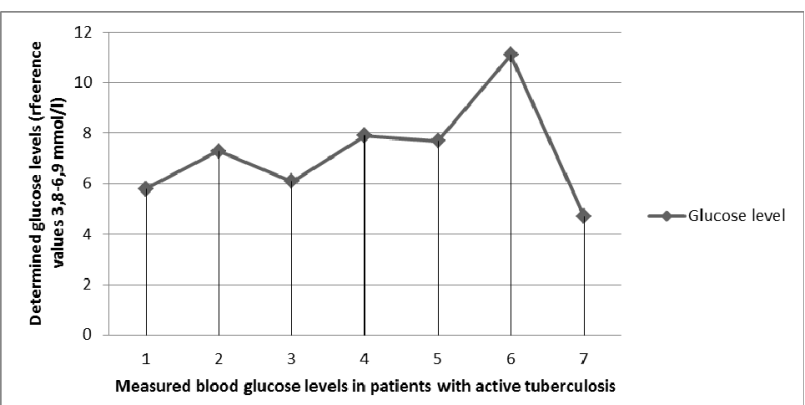

Figure 2. Graphic presentation of the established blood glucose levels in female patients with active tuberculosis

Poorly controlled diabetes can lead to multiple complications, including vascular disease, neuropathy, and increased susceptibility to infection. Diabetes might also lead to increased susceptibility to disease caused by Mycobacterium tuberculosis via multiple mechanisms. The mechanisms include those directly related to hyperglycaemia and cellular insulinopenia, as well as indirect effects on macrophage and lymphocyte function, leading to diminished ability to contain the organism. The most important effector cells for containment of tuberculosis are phagocytes (alveolar macrophages and their precursor monocytes) and lymphocytes. Diabetes is known to affect 
chemotaxis, phagocytosis, activation, and antigen presentation by phagocytes in response to $M$. tuberculosis. In diabetic patients, chemotaxis of monocytes is impaired, and this defect does not improve with insulin.

\section{Discussion}

Several case-control studies have shown that the relative odds of developing tuberculosis in diabetic patients ranges from 2.44 to 8.33 compared with non-diabetic patients $(17,18,19,20)$. Several largescale longitudinal cohort studies have shown similar findings. In Korea, a 3-year longitudinal study involving 800000 civil servants showed that the risk ratio of tuberculosis in diabetic patients versus non-diabetic controls was 3.47 (95\% CI 2.98-4.03) (21). These large studies involving thousands of participants provide convincing data that diabetes mellitus is a moderate-to-strong risk factor for the development of active tuberculosis. In our study we found that there is a link between patients with high glucose blood level and active pulomonary tuverculosis. We can say that diabetes is associated with a decrease in cellular immunity.

Diabetes and tuberculosis should be treated aggressively with insulin. In case a person with diabetes and active tuberculosis is poorly controlled on oral hypoglycemic agents, it is necessary to switch to insulin. The choice of insulin regime should be based on efficacy, safety, tolerability and convenience (22).

\section{Conclusion}

Diabetes has long been known to be a risk factor for active tuberculosis and reactivation of latent tuberculosis. Early screening of DM2 and/or treatment with tight glycemic control in individuals hospitalized for TBC might be able to decrease the mortality associated in patients with both diagnoses on admission. Patients with diabetes with a poor treatment adherence and a $\mathrm{HbA1C}>6 \%$ could be a risk group for developing TBC, probably due to the long term immunosuppressive state thus generated. Considering the increasing disease burden of DM, particularly in areas with highly prevalent TB, TB control programs will need to expand their efforts and focus on treating and monitoring patients with $\mathrm{DM}$ and TB disease. The findings of this study point to another challenge for the control of TB. It is possible that, despite their importance, the traditional existing measures that do not consider the convergence between $\mathrm{DM}$ and $\mathrm{TB}$ are not sufcient.

\section{References}

1. Parvaneh Baghaei, Majid Marjani, Pedram Javanmard, Payam Tabarsi and Mohammad Reza Masjedi. Diabetes mellitus and tuberculosis facts and controversies. Baghaei et al. Journal of Diabetes \& Metabolic Disorders 2013, 12:58.

2. Dooley KE, Chaisson RE. TB and diabetes mellitus: convergence of two epidemics. Lancet Infect Dis. 2009;9:737-46.

3. World Health Organization and International Union against TB and Lung Disease. Collaborative framework for care and control of TB and diabetes [cited 2015 Feb 16].

4. Dooley KE, Chaisson RE. Tuberculosis and diabetes mellitus: convergence of two epidemics.Lancet Infect Dis. 2009;9(12):737-46. DOI:10.1016/S14733099(09)70282-8

5. World Health Organization. The global plan to stop TB 2006-2015: actions for life: towards a world free of tuberculosis: stop TB partnership. Geneva: World Health Organization; 2006.

6. Dooley KE, Tang T, Golub JE, Dorman SE, Cronin W. Impact of diabetes mellitus on treatment outcomes of patients with active tuberculosis. Am J Trop Med Hyg. 2009;80(4):634-9.

7. Orofno RL, Brasil PEAd, Trajman A, Schmaltz CAS, Dalcolmo M, Rolla VC. Preditores dos desfechos do tratamento da tuberculose. J Bras Pneumol. 2012;38(1):88-97.

8. Magee MJ, Bloss E, Shin SS, Contreras C, Huaman HA, Ticona JC et al. Clinical characteristics, drug resistance, and treatment outcomes among tuberculosis patients with diabetes in Peru. Int $\mathrm{J}$ Infect Dis. 2013;17(6):e404-12.

9. Guariguata L, Whiting DR, Hambleton I, Beagley J, Linnenkamp U, Shaw JE. Global estimates of diabetes prevalence for 2013 and projections for 2035. Diabetes Res Clin Pract. 2014;103(2):137-49.

DOI:10.1016/j.diabres.2013.11.002.

10. Amin S, Khattak MI, Shabbier G, Wazir MN. Frequency of pulmonary tuberculosis in patients with diabetes mellitus. Gomal Journal of Medical Sciences. 2012;9(2).

11. Harries A, Satyanarayana S, Kumar A, Nagaraja S, Isaa-kidis $\mathrm{P}$, Malhotra $\mathrm{S}$, et al. Epidemiology and interaction of diabetes mellitus and tuberculosis and 
challenges for care: a review. Public Health Action. 2013;3(Suppl 1):S3.

12. Dooley KE, Chaisson RE. Tuberculosis and diabetes mellitus: convergence of two epidemics. The Lancet Infectious Diseases. 2009;9(12):737-46.

13. Mealey BL (2000) Diabetes and periodontal disease: two sides of a coin. Compend Contin Educ Dent 21: 943-946, 948, 950, passim.

14. Geerlings SC, Hopelman AI: Immune dysfunction in patients with diabetes mellitus (DM). FEMS Immunol Med Microbiol 1999, 26:259-65

15. Atkin SL, Masson EA, Bodmer CW, Walker BA, White MC: Increased insulin requirement in a patient with Type 1 diabetes on rifampicin [letter]. Diabet Med 1993, 10: 392. 10.1111/j.1464-5491.1993.tb00086.x

16. Atkin SL, Masson EA, Bodmer CW, Walker BA, White MC: Increased insulin requirement in a patient with Type 1 diabetes on rifampicin [letter]. Diabet Med 1993, 10: 392. 10.1111/j.1464-5491.1993.tb00086.x

17. Lebovitz HE: Oral hypoglycemic agents. Ellenberg and Rifkins's diabetes mellitus, theory and practice. 4th ed. New York: Elsevier: Rifkin H, Porte Jr D, eds; 1990:554-574.
18. Mboussa J, Monabeka H, Kombo M, Yokolo D, YokaMbio A, Yala F. Course of pulmonary tuberculosis in diabetics. Rev Pneumol Clin 2003;59:39-44.

19. Shetty N, Shemko M, Vaz M, D'souza G. An epidemiological evaluation of risk factors for tuberculosis in South India: a matched case control study. Int J Tuberc Lung Dis 2006;10:80-86.

20. Coker R, McKee M, Atun R, et al. Risk factors for pulmonary tuberculosis in Russia: case-control study. BMJ 2006;332:85-87. [PubMed: 16339219]

21. Jabbar A, Hussain SF, Khan AA. Clinical characteristics of pulmonary tuberculosis in adult Pakistani patients with coexisting diabetes mellitus. East Mediterr Health J 2006;12:522-27.

22. Kim SJ, Hong YP, Lew WJ, Yang SC, Lee EG. Incidence of pulmonary tuberculosis among diabetics. Tuber Lung Dis 1995;76:529-33. [PubMed: 8593374].

23. Jeon CY, Murray MB. Diabetes mellitus increases the risk of active tuberculosis: a systematic review of 13 observational studies. PLoS Med 2008;5:e152. [PubMed: 18630984]

24. Asfandyar Khan, NiaziEmail and Sanjay Kalra. Diabetes and tuberculosis: a review of the role of optimal glycemic control. Journal of Diabetes \& Metabolic Disorders; 201211:28

Sažetak:Uvod: Povezanost između dijabetesa mellitus (DM) i TB predstavlja važan izazov za globalnu kontrolu TB. Pacijenti sa ova dva stanja mogu predstaviti visoke stope neuspjeha liječenja tuberkuloze i povećanog rizika od smrti.

Cilj istraživanja: Cilj ovog istraživanja je da se utvrdi broj pacijenata sa aktivnom plućnom tuberkulozom u srednjoj Bosni, od Februar 2016 - $i$ do aprila 2017. prema dobi i spolu. Zatim utvrditi da li postoji korelacija između plućne tuberkuloze s nivoom glukoze u krvi.

Materijal i metode: U razdoblju od veljače 2016. do April 2017. -te otkrili smo 26 pacijenata sa aktivnom tuberkulozom pluća, od kojih je 19 pacijenata muškog spola i sedam ženskog. Pacijentima je urađena analiza krvne slike, između ostalog, određen nivo glukoze u krvi (mmol / l) koristeći AMS (Analayze Medical System) prema uputsvu proizvođača.

Rezultati: Od ukupno 26 bolesnika s aktivnom plućnom tuberkulozom kod četiri pacijenta je pronađen nivo šećera na granic ili iznad referentne vrijednosti. Od sedam pacijentica sa aktivnom tuberkulozom u četiri se utvrdi da imaju povišen nivo glukoze u krvi.

Zaključak: U našoj studiji ustanovili smo da postoji veza između pacijenata sa visokim nivoom glukoze u krvi i aktivne plućne tuberkuloze.

Corresponding autor:

Hadžić Vildana

E mail adress: hadzicvildana@yahoo.com

Hospital for Respiratory diseases and TBC, Travnik 